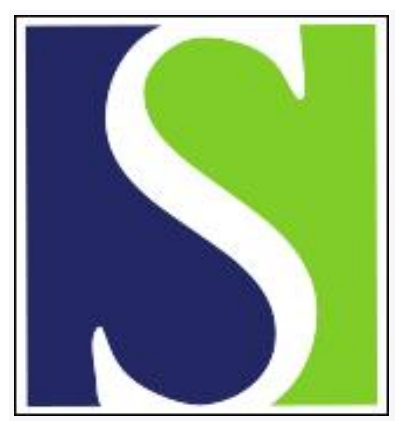

Scand J Work Environ Health 2001;27(1):57-62

https://doi.org/10.5271/sjweh.587

Issue date: Feb 2001

Life-style intervention at the worksite - reduction of cardiovascular risk factors in a randomized study

by Nilsson PM, Klasson E-B, Nyberg P

Affiliation: Department of Community Medicine, University hospital, S-205 02 Malmö, Sweden. Peter.Nilsson@medforsk.mas.lu.se

The following article refers to this text: 2010;36(3):202-215

Key terms: cardiovascular risk factor; life-style intervention; lipids; randomized study; risk factor; screening; smoking; workplace; worksite

This article in PubMed: www.ncbi.nlm.nih.gov/pubmed/11266148 


\title{
Life-style intervention at the worksite - reduction of cardiovascular risk factors in a randomized study
}

\author{
by Peter M Nilsson, MD, ${ }^{1}$ Eva-Birgitta Kasson, $R N^{2}$ Per Nyberg, $P h D^{1}$
}

\begin{abstract}
Nilsson PM, Kasson E-B, Nyberg P. Life-style intervention at the worksite - reduction of cardiovascular risk factors in a randomized study. Scand J Work Environ Health 2001;27(1):57-62.

Objectives This study tested a feasible method for screening for cardiovascular risk at the worksite and investigated the effects of a long-term comprehensive program of life-style intervention to prevent cardiovascular disease.

Methods Employees in the public sector filled out a self-administered questionnaire with questions on social, medical, and work-related factors. The respondents numbered 454 (80\%). A score sum for cardiovascular risk was calculated (range 1-20, median 7.0), and the 128 subjects with a sum above 8 were invited to a health examination including blood sampling. Thereafter the subjects were invited to participate, following randomization, in a comprehensive, 18-month, life-style intervention program to improve cardiovascular risk or in a control group.

Results The intervention group significantly decreased body mass index, diastolic blood pressure, heart rate, low-density lipoprotein (LDL) cholesterol, and smoking habits during the intervention. The initially elevated serum cortisol, as a marker of stress reaction, normalized in the intervention group. In the control group LDL cholesterol also decreased, but the glucose and triglyceride levels increased, and smoking habits were unchanged. Sick days for a given period decreased after 1 year in the intervention group but not in the control group.

Conclusions Several cardiovascular risk factors can be improved and morning serum cortisol normalized during a long-term life-style intervention program with a randomized design using a worksite population of middleaged subjects. The use of a 2-step screening program, with an initial questionnaire followed by a health check of subjects with elevated risk, is feasible for worksite settings.
\end{abstract}

Key terms intervention, lipids, risk factor, screening, smoking, workplace.

Cardiovascular morbidity and mortality are still of great importance for public health in Sweden, with widening health gaps in the working population (1). New guidelines on the prevention of cardiovascular risk factors have focused on individual risk calculations based on data on smoking, hypertension, and hyperlipidemia, as well as data on other risk factors $(2,3)$. In most cases of primary cardiovascular prevention, an initial period of life-style modification is advocated, including weight reduction among the obese, smoking cessation, improved diet and physical activity, all well-established components as previously discussed in detail $(2,3)$. Such change is, however, not always easy to accomplish, and numerous studies have addressed the difficulties of implementing life-style programs in unselected healthy populations, even if sometimes impressing results have been achieved (4). In Sweden several population-based studies have initiated life-style programs among cardiovascular risk patients with varying results (5-8). Not many studies have, however, been randomized or have lasted long enough to permit conclusions to be drawn about the methodology and effects.

At the worksite, cardiovascular prevention is a matter of great importance because many employees have to leave the workforce prematurely each year due to the health consequences of ischemic heart disease. However, so far not many randomized intervention studies

1 Department of Community Medicine, University of Lund, Lund, Sweden.

2 Occupational Health Care, Helsingborg City, Sweden.

Reprint requests to: Dr Peter Nilsson, Department of Community Medicine, University hospital, S-205 02 Malmö, Sweden. [E-mail: Peter.Nilsson@medforsk.mas.lu.se] 
have been published on the prevention of cardiovascular disease (CVD) at the worksite $(9-11)$. It is also still unclear which method of screening for cardiovascular risk factors should be recommended in this setting, as traditional screening programs (eg, with blood sampling on a broad basis) are often costly, time-consuming, and of limited value (12). In addition, traditional cardiovascular screening does not always take psychosocial factors and stress into account, in spite of their importance for cardiovascular health (13) and general well-being. One interesting laboratory marker of stress is serum cortisol (14), and a good marker of aging and anabolism or catabolism is dehydroepiandrosterone (DHEA) (15), both seldom used in the evaluation of life-style intervention studies.

The aim of the present study was 2-fold, namely, to test a feasible method of screening for cardiovascular risk patients at the worksite and to test the effects of a comprehensive program of life-style intervention to prevent CVD (eg, special care in comparison with usual care).

\section{Subjects and methods}

\section{Subjects and screening}

Helsingborg is a city in southern Sweden with 110000 inhabitants. Many persons belonging to the employed part of the population work in the public sector with the city council of Helsingborg as their main employer. In this study we initially selected 4 branches of the local public sector with a total of 568 employees, most of them middle-aged women between 40 and 50 years of age, who worked as nurses, cleaners, gardeners, drivers, or transportation workers.

The 1 st step in the screening procedure was to hand out a self-administered questionnaire with 54 questions on family history of cardiovascular disease, current lifestyle, medical history, and current treatment, as well as psychosocial factors, social network characteristics, and work-related stressors. The questionnaire was completed by 454 subjects ( $80 \%$ response rate). All the questions were allocated a cardiovascular risk score based on known associations with CVD. The sum of the risk scores (range $1-20$, median 7.0) was calculated for each respondent.

The persons $(\mathrm{N}=128)$ with a risk score sum of $\geq 9$ were randomized into a life-style intervention study for 18 months and then invited for an individual health check including a physical examination by nurses. Blood sampling was carried out within 1 week after the health check and randomization procedure. An intermediate health check was offered at 12 months. Of the 65 subjects randomized into the intervention group, 5 did not show up for the baseline health examination, 16 were dropouts or excluded for medical reasons at 12 months, and 1 subject was lost to follow-up at 18 months. In the control group of 63 invited subjects, the corresponding figures were 10, 5, and 2 subjects, respectively. Therefore, at 12 months, a total of 44 subjects from the intervention group and 48 from the control group could be evaluated, and after 18 months the corresponding numbers were 43 and 46 subjects, respectively.

The persons who dropped out before the baseline health examination were more often divorced, smokers, or on long-term sick leave than were the participants. With respect to the baseline variables, the other dropouts during the study did not differ from subjects followed for the whole study period.

There were no differences in age or gender between the intervention and control groups at the beginning of the study. The mean age of the initially participating 56 women and 36 men was 49.7 (range 28-65) years.

\section{Physical examination}

The subjects were weighed in light indoor clothing, and their height was measured without shoes. Their body mass index (BMI) was calculated. The waist was measured at the umbilicus level and the hip measurement was taken at the widest part of the hips. A waist-to-hip ratio was calculated. Pulse rate and blood pressure were measured twice, using a cuff of appropriate size, after 10 minutes of supine rest, and the mean figures of the 2 measurements were recorded.

\section{Laboratory investigation}

Blood samples were drawn for blood glucose, hemoglobin, serum lipids [total cholesterol, low-density lipoprotein (LDL) cholesterol, high-density lipoprotein (HDL) cholesterol, and triglycerides], gamma glutamyl transferases, alkaline phosphatase, cortisol, plasma insulin, and plasma DHEA in the morning (between 0730 - 0900) after overnight fasting. All the variables were analyzed at the Department of Clinical Chemistry, Helsingborg Hospital, except DHEA, which was analyzed at the Department of Clinical Chemistry, University Hospital, Malmö, using routine methods. LDL cholesterol was calculated according to Friedewald's formula after analyses for other lipid variables (AXON $^{\text {TM }}$ System, Technicon, Diagnostic Division, Terrytown, NY, USA).

\section{Life-styleintervention}

The subjects randomized into the comprehensive program of life-style intervention ("special care") were offered 16 group sessions a year with educational and practical content, in addition to individual counseling by a nurse. All the activities took place outside the workplace, at a health center, but were scheduled during 
workhours to improve the attendance rates. Weight reduction among the obese, improved diet, and physical activity, as well as stress management and smoking cessation, were all part of this program, based on lectures, discussions, video sessions, and outdoor activities. The program continued for 18 months with new health checks at 12 and 18 months. The subjects randomized into the control group received standard written and oral advice about cardiovascular risk factors at the beginning of the intervention ("usual care"), but they did not participate in any other activities. In both groups the persons on medication (including antihypertensives) were asked not to change the treatment during the study period in order to avoid any drug interference with the outcome variables (blood pressure and metabolism); otherwise they were excluded.

\section{Time spent by staff}

One full-time and one part-time nurse spent a total of 200 hours on the group sessions, including preparation time, and about 450 hours on individual counseling for the subjects belonging to the intervention group. In addition, other people, such as nutritionists, physiotherapists and a physician, spent about 30 hours altogether on lectures or practical training for the group members (eg, cooking). Therefore a final total of about 680 hours was spent on the project, not including the time needed for the blood sampling.

\section{Registered sick days}

The mean number of sick days was registered for a 4month period (September-December) during the 1 st and 2nd year of the study.

\section{Statistics}

Means and standard deviations have been given for the variables in the tables. Intragroup comparisons between the baseline and follow-up (12 and 18 months) values were carried out by use of an analysis of variance (ANOVA) for linear trends in repeated measurements. Intergroup comparisons were carried out by use of an analysis of covariance (ANCOVA). A chi-square test was used to compare proportions. The results for skewed variables such as insulin and triglycerides were logtransformed before the calculations. The baseline cortisol levels were compared between the groups with an unpaired Student's t-test. Changes in the mean number of sick days within the groups were compared with a paired t-test. Logistic regression analyses were used to calculate the differences in sedentary life-style and smoking status. A P-value of $<0.05$ was considered significant.

\section{Results}

In the intervention group a significant reduction trend (ANOVA) was recorded for BMI $\left(-0.7 \mathrm{~kg} / \mathrm{m}^{2}\right.$ after 12 months and $-0.5 \mathrm{~kg} / \mathrm{m}^{2}$ after 18 months), diastolic blood pressure $[-5.4 \mathrm{~mm} \mathrm{Hg}(-0.09 \mathrm{kPa})$ after 12 months and $-5.7 \mathrm{~mm} \mathrm{Hg}(-0.76 \mathrm{kPa})$ after 18 months], heart rate $(-1.4$ beats/min after 12 months and -3.5 beats/min after 18 months), LDL cholesterol $(-0.3 \mathrm{mmol} / \mathrm{l}$ after 12 months and $-0.3 \mathrm{mmol} / \mathrm{l}$ after 18 months), and the LDL:HDL ratio ( -0.5 after 12 months and -0.5 after 18 months), but an increasing trend for HDL cholesterol

Table 1. Results of the life-style intervention on the clinical variables of the cardiovascular risk patients $(\mathrm{N}=43)$ and controls $(\mathrm{N}=46)$. The results of the analysis of variance (ANOVA) for linear trends in repeated measurements within groups and the analysis of covariance (ANCOVA) for differences between groups are also presented. (BMI = body mass index)

\begin{tabular}{|c|c|c|c|c|c|c|c|c|c|c|}
\hline \multirow[t]{3}{*}{ Time of measurement } & \multirow{2}{*}{\multicolumn{2}{|c|}{$\begin{array}{l}\text { BMl } \\
\left(\mathrm{kg} / \mathrm{m}^{2}\right)\end{array}$}} & \multirow{2}{*}{\multicolumn{2}{|c|}{ Waist:hip ratio }} & \multicolumn{4}{|c|}{ Blood pressure } & \multirow{2}{*}{\multicolumn{2}{|c|}{ Heart rate (beats/min) }} \\
\hline & & & & & \multicolumn{2}{|c|}{ Systolic $\left(\mathrm{mm} \mathrm{Hg}^{\mathrm{a}}\right)$} & \multicolumn{2}{|c|}{ Diastolic $\left(\mathrm{mm} \mathrm{Hg}^{\mathrm{a}}\right)$} & & \\
\hline & Mean & $\mathrm{SD}$ & Mean & $\mathrm{SD}$ & Mean & SD & Mean & $\mathrm{SD}$ & Mean & $\mathrm{SD}$ \\
\hline \multicolumn{11}{|l|}{ Baseline } \\
\hline Intervention group & 28.8 & 5.9 & 0.86 & 0.07 & 132.2 & 18.7 & 78.7 & 10.0 & 68.1 & 9.1 \\
\hline Control group & 26.7 & 5.2 & 0.86 & 0.09 & 132.9 & 17.1 & 75.9 & 9.3 & 70.5 & 9.0 \\
\hline \multicolumn{11}{|l|}{12 months } \\
\hline Intervention group & 28.1 & 5.7 & 0.85 & 0.08 & 127.6 & 14.9 & 73.3 & 9.3 & 66.7 & 8.9 \\
\hline Control group & 26.8 & 4.6 & 0.86 & 0.09 & 130.2 & 15.5 & 74.8 & 9.2 & 68.8 & 7.2 \\
\hline \multicolumn{11}{|l|}{18 months } \\
\hline Intervention group & 28.3 & 5.7 & 0.86 & 0.07 & 128.5 & 21.6 & 73.0 & 11.3 & 64.6 & 8.0 \\
\hline Control group & 26.7 & 4.6 & 0.87 & 0.08 & 131.7 & 18.6 & 75.5 & 9.8 & 68.2 & 7.3 \\
\hline \multicolumn{11}{|l|}{ ANOVA } \\
\hline Intervention group & \multirow{2}{*}{\multicolumn{2}{|c|}{$\begin{array}{l}0.032 \\
0.732\end{array}$}} & \multirow{2}{*}{\multicolumn{2}{|c|}{$\begin{array}{l}0.261 \\
0.394\end{array}$}} & \multirow{2}{*}{\multicolumn{2}{|c|}{$\begin{array}{l}0.101 \\
0.554\end{array}$}} & \multirow{2}{*}{\multicolumn{2}{|c|}{$\begin{array}{l}0.001 \\
0.808\end{array}$}} & \multirow{2}{*}{\multicolumn{2}{|c|}{$\begin{array}{l}0.006 \\
0.071\end{array}$}} \\
\hline Control group & & & & & & & & & & \\
\hline \multicolumn{11}{|l|}{ ANCOVA } \\
\hline Intervention group & \multicolumn{2}{|c|}{0.021} & \multicolumn{2}{|c|}{0.156} & \multicolumn{2}{|c|}{0.652} & \multicolumn{2}{|c|}{0.022} & \multicolumn{2}{|c|}{0.668} \\
\hline
\end{tabular}

a $1 \mathrm{mmHg} \approx 0.133 \mathrm{kPa}$ 
Table 2. Results of the life-style intervention on the laboratory variables of the cardiovascular risk patients ( $\mathrm{N}=43$ ) and controls ( $\mathrm{N}=46)$. The for differences between groups are also presented. $(\mathrm{C}=$ cholesterol, $\mathrm{LDL}-\mathrm{C}=$ low-density lipoprotein cholesterol, $\mathrm{HDL}-\mathrm{C}=\mathrm{high}-\mathrm{density}$ able at 18 months)

\begin{tabular}{|c|c|c|c|c|c|c|c|c|c|c|}
\hline \multirow[t]{2}{*}{ Time of measurement } & \multicolumn{2}{|c|}{ Hemoglobin (g/l) } & \multicolumn{2}{|c|}{ Total C (mmol/l) } & \multicolumn{2}{|c|}{ LDL-C (mmol/ll) } & \multicolumn{2}{|c|}{$\mathrm{HDL}-\mathrm{C}(\mathrm{mmol} / \mathrm{l})$} & \multicolumn{2}{|c|}{ LDL:HDL ratio } \\
\hline & Mean & $\mathrm{SD}$ & Mean & SD & Mean & SD & Mean & SD & Mean & SD \\
\hline \multicolumn{11}{|l|}{ Baseline } \\
\hline $\begin{array}{l}\text { Intervention group } \\
\text { Control group }\end{array}$ & $\begin{array}{l}141.7 \\
141.1\end{array}$ & $\begin{array}{l}12.0 \\
12.0\end{array}$ & $\begin{array}{l}5.8 \\
5.7\end{array}$ & $\begin{array}{l}0.9 \\
1.0\end{array}$ & $\begin{array}{l}4.00 \\
3.86\end{array}$ & $\begin{array}{l}0.85 \\
0.97\end{array}$ & $\begin{array}{l}1.21 \\
1.24\end{array}$ & $\begin{array}{l}0.30 \\
0.31\end{array}$ & $\begin{array}{l}3.55 \\
3.29\end{array}$ & $\begin{array}{l}1.28 \\
1.08\end{array}$ \\
\hline \multicolumn{11}{|l|}{12 months } \\
\hline $\begin{array}{l}\text { Intervention group } \\
\text { Control group }\end{array}$ & $\begin{array}{l}144.0 \\
142.2\end{array}$ & $\begin{array}{l}11.4 \\
10.7\end{array}$ & $\begin{array}{l}5.7 \\
5.7\end{array}$ & $\begin{array}{l}0.8 \\
1.0\end{array}$ & $\begin{array}{l}3.74 \\
3.79\end{array}$ & $\begin{array}{l}0.78 \\
0.87\end{array}$ & $\begin{array}{l}1.32 \\
1.26\end{array}$ & $\begin{array}{l}0.30 \\
0.34\end{array}$ & $\begin{array}{l}3.07 \\
3.21\end{array}$ & $\begin{array}{l}1.15 \\
1.03\end{array}$ \\
\hline \multicolumn{11}{|l|}{18 months } \\
\hline $\begin{array}{l}\text { Intervention group } \\
\text { Control group }\end{array}$ & $\begin{array}{l}141.1 \\
141.3\end{array}$ & $\begin{array}{r}9.0 \\
10.7\end{array}$ & $\begin{array}{l}5.7 \\
5.7\end{array}$ & $\begin{array}{l}0.9 \\
1.1\end{array}$ & $\begin{array}{l}3.71 \\
3.71\end{array}$ & $\begin{array}{l}0.77 \\
0.97\end{array}$ & $\begin{array}{l}1.27 \\
1.28\end{array}$ & $\begin{array}{l}0.30 \\
0.33\end{array}$ & $\begin{array}{l}3.10 \\
3.07\end{array}$ & $\begin{array}{l}1.01 \\
1.09\end{array}$ \\
\hline \multicolumn{11}{|l|}{ ANOVA } \\
\hline $\begin{array}{l}\text { Intervention group } \\
\text { Control group }\end{array}$ & \multicolumn{2}{|c|}{$\begin{array}{l}0.612 \\
0.864\end{array}$} & \multicolumn{2}{|c|}{$\begin{array}{l}0.537 \\
0.690\end{array}$} & \multicolumn{2}{|c|}{$\begin{array}{l}0.005 \\
0.049\end{array}$} & \multicolumn{2}{|c|}{$\begin{array}{l}0.029 \\
0.160\end{array}$} & \multicolumn{2}{|c|}{$\begin{array}{l}0.001 \\
0.019\end{array}$} \\
\hline \multicolumn{11}{|l|}{ ANCOVA } \\
\hline Intervention group & \multicolumn{2}{|c|}{0.255} & \multicolumn{2}{|c|}{0.769} & \multicolumn{2}{|c|}{0.259} & \multicolumn{2}{|c|}{0.038} & \multicolumn{2}{|c|}{0.056} \\
\hline
\end{tabular}

Table 3. Results of the life-style intervention on the risk scores and life-style variables of the cardiovascular risk patients $(\mathrm{N}=43)$ and controls $(\mathrm{N}=46)$. The results of the analysis of variance (ANOVA) for linear trends in repeated measurements within groups, and the analysis of covariance (ANCOVA) for differences between groups are also presented.

\begin{tabular}{|c|c|c|c|c|}
\hline \multirow[t]{2}{*}{ Time of measurement } & \multicolumn{2}{|c|}{ Risk score } & \multirow{2}{*}{$\begin{array}{c}\text { Sedentary } \\
\text { life-style } \\
(\%)\end{array}$} & \multirow{2}{*}{$\begin{array}{c}\text { Daily } \\
\text { smokers } \\
(\%)\end{array}$} \\
\hline & Mean & SD & & \\
\hline \multicolumn{5}{|l|}{ Baseline } \\
\hline $\begin{array}{l}\text { Intervention group } \\
\text { Control group }\end{array}$ & $\begin{array}{l}10.3 \\
10.8\end{array}$ & $\begin{array}{l}1.5 \\
2.2\end{array}$ & $\begin{array}{l}30 \\
33\end{array}$ & $\begin{array}{l}65 \\
65\end{array}$ \\
\hline \multicolumn{5}{|l|}{12 months } \\
\hline $\begin{array}{l}\text { Intervention group } \\
\text { Control group }\end{array}$ & $\begin{array}{r}8.0 \\
10.2\end{array}$ & $\begin{array}{l}2.1 \\
2.3\end{array}$ & $\begin{array}{l}26 \\
37\end{array}$ & $\begin{array}{l}37 \\
63\end{array}$ \\
\hline \multicolumn{5}{|l|}{18 months } \\
\hline $\begin{array}{l}\text { Intervention group } \\
\text { Control group }\end{array}$ & $\begin{array}{r}9.0 \\
10.0\end{array}$ & $\begin{array}{l}2.2 \\
2.2\end{array}$ & $\begin{array}{l}26 \\
28\end{array}$ & $\begin{array}{l}40 \\
59\end{array}$ \\
\hline \multicolumn{5}{|l|}{ ANOVA } \\
\hline $\begin{array}{l}\text { Intervention group } \\
\text { Control group }\end{array}$ & $\begin{array}{l}0.001 \\
0.009\end{array}$ & & $\begin{array}{l}0.628 \\
0.514\end{array}$ & $\begin{array}{l}0.018 \\
0.519\end{array}$ \\
\hline \multicolumn{5}{|l|}{ ANCOVA } \\
\hline Intervention group & 0.001 & & 0.656 & 0.034 \\
\hline
\end{tabular}

(0.1 mmol/l after 12 months and $0.1 \mathrm{mmol} / \mathrm{l}$ after 18 months $)$ and triglycerides $(0.2 \mathrm{mmol} / \mathrm{l}$ after 12 months and $0.3 \mathrm{mmol} / \mathrm{l}$ after 18 months).

In the control group a significant reduction trend was recorded for LDL cholesterol $(-0.1 \mathrm{mmol} / \mathrm{l}$ after 12 months and $-0.2 \mathrm{mmol} / \mathrm{l}$ after 18 months) and the LDL:HDL ratio ( -0.1 after 12 months and -0.2 after 18 months), but an increasing trend was found for triglycerides $(0.2 \mathrm{mmol} / \mathrm{l}$ after $12 \mathrm{months}$ and $0.2 \mathrm{mmol} /$ 1 after 18 months $)$ and glucose $(0.2 \mathrm{mmol} / 1$ after 12 months and $0.4 \mathrm{mmol} / \mathrm{l}$ after 18 months). Significant group differences for trend (ANCOVA) were recorded for BMI, diastolic blood pressure, and HDL cholesterol, all in favor of the intervention group [table 1 (on page 59) and table 2].

Serum cortisol differed between the groups already at the beginning of the study in that the intervention group showed a higher mean level, 479 (SD 134) nmol/ 1, than the control group, 420 (SD 137) nmol/l $(\mathrm{P}=0.043)$. Cortisol was later normalized, and no significant differences within or between the groups were evident by the end of the study. DHEA did not change in either group (table 2).

The smoking prevalence decreased in the intervention group, from $65 \%$ at the beginning of the study to $37 \%$ (12 months) and 40\% (18 months), but no change was recorded in the control group, and therefore a significant group difference was recorded (ANCOVA). This difference influenced the decrease in the mean risk score, from 10.3 (SD 1.5) to 9.0 (SD 2.2), after 18 months in the intervention group $(\mathrm{P}=0.042)$. The risk score also decreased in the control group, but, since the decrease was smaller, a significant group difference was recorded between the groups (ANCOVA). No difference in either group was recorded for the proportion of sedentary subjects (table 3 ).

The mean number of sick days in the last 4-month period of the year decreased in the intervention group from 6.0 (SD 16.5) at the beginning of the study to 2.9 (SD 9.4) during a similar period after 1 year $(\mathrm{P}=0.03)$, but increased in the control group from 4.5 (SD 12.0) to 7.4 (SD 22.7) during the same period $(\mathrm{P}=0.04)$. 
results of the analysis of variance (ANOVA) for linear trends in repeated measurements within groups and the analysis of covariance (ANCOVA) lipoprotein cholesterol, $\gamma$-GT $=$ gamma glutamyl transferase, ALP $=$ alkaline phosphatase, DHEAS = dehydroepiandrosterone, $N A=$ not avail-

\begin{tabular}{|c|c|c|c|c|c|c|c|c|c|c|c|c|c|}
\hline \multicolumn{2}{|c|}{ Triglycerides (mmol/l) } & \multicolumn{2}{|c|}{ Gucose (mmol/l) } & \multicolumn{2}{|c|}{ Insulin (mU/l) } & \multicolumn{2}{|c|}{$\gamma$-GT (kat/l) } & \multicolumn{2}{|c|}{ ALP (kat/l) } & \multicolumn{2}{|c|}{ Cortisol (nmol/l) } & \multicolumn{2}{|c|}{ DHEAS $(\mathrm{mol} / \mathrm{l})$} \\
\hline Mean & SD & Mean & SD & Mean & SD & Mean & SD & Mean & SD & Mean & SD & Mean & SD \\
\hline $\begin{array}{l}1.31 \\
1.36\end{array}$ & $\begin{array}{l}0.66 \\
0.75\end{array}$ & $\begin{array}{l}4.84 \\
5.05\end{array}$ & $\begin{array}{l}0.61 \\
1.65\end{array}$ & $\begin{array}{l}9.5 \\
7.9\end{array}$ & $\begin{array}{l}6.4 \\
4.7\end{array}$ & $\begin{array}{l}0.38 \\
0.49\end{array}$ & $\begin{array}{l}0.18 \\
0.44\end{array}$ & $\begin{array}{l}2.55 \\
2.55\end{array}$ & $\begin{array}{l}0.69 \\
0.81\end{array}$ & $\begin{array}{l}478.8 \\
419.8\end{array}$ & $\begin{array}{l}133.8 \\
136.5\end{array}$ & $\begin{array}{l}4.78 \\
4.66\end{array}$ & $\begin{array}{l}2.60 \\
2.48\end{array}$ \\
\hline $\begin{array}{l}1.46 \\
1.53\end{array}$ & $\begin{array}{l}0.66 \\
0.88\end{array}$ & $\begin{array}{l}4.95 \\
5.23\end{array}$ & $\begin{array}{l}0.69 \\
2.19\end{array}$ & $\begin{array}{r}10.0 \\
7.8\end{array}$ & $\begin{array}{l}8.6 \\
4.0\end{array}$ & $\begin{array}{l}0.40 \\
0.45\end{array}$ & $\begin{array}{l}0.21 \\
0.27\end{array}$ & $\begin{array}{l}2.74 \\
2.50\end{array}$ & $\begin{array}{l}0.85 \\
0.76\end{array}$ & $\begin{array}{l}420.8 \\
410.2\end{array}$ & $\begin{array}{l}153.1 \\
111.2\end{array}$ & $\begin{array}{l}4.59 \\
4.71\end{array}$ & $\begin{array}{l}2.51 \\
2.79\end{array}$ \\
\hline $\begin{array}{l}1.63 \\
1.59\end{array}$ & $\begin{array}{l}0.89 \\
0.78\end{array}$ & $\begin{array}{l}4.96 \\
5.40\end{array}$ & $\begin{array}{l}0.53 \\
1.97\end{array}$ & $\begin{array}{l}9.0 \\
7.4\end{array}$ & $\begin{array}{l}4.8 \\
3.9\end{array}$ & $\begin{array}{l}0.42 \\
0.52\end{array}$ & $\begin{array}{l}0.28 \\
0.37\end{array}$ & $\begin{array}{l}2.67 \\
2.54\end{array}$ & $\begin{array}{l}0.85 \\
0.74\end{array}$ & $\begin{array}{l}473.5 \\
448.7\end{array}$ & $\begin{array}{l}124.2 \\
130.3\end{array}$ & $\begin{array}{l}\text { NA } \\
\text { NA }\end{array}$ & \\
\hline \multicolumn{2}{|c|}{$\begin{array}{l}0.003 \\
0.001\end{array}$} & \multicolumn{2}{|c|}{$\begin{array}{l}0.107 \\
0.001\end{array}$} & \multicolumn{2}{|c|}{$\begin{array}{l}0.414 \\
0.556\end{array}$} & \multicolumn{2}{|c|}{$\begin{array}{l}0.223 \\
0.419\end{array}$} & \multicolumn{2}{|c|}{$\begin{array}{l}0.150 \\
0.887\end{array}$} & \multicolumn{2}{|c|}{$\begin{array}{l}0.823 \\
0.207\end{array}$} & \multicolumn{2}{|c|}{$\begin{array}{l}0.359 \\
0.781\end{array}$} \\
\hline \multicolumn{2}{|c|}{0.600} & \multicolumn{2}{|c|}{0.054} & \multicolumn{2}{|c|}{0.964} & \multicolumn{2}{|c|}{0.279} & \multicolumn{2}{|c|}{0.114} & \multicolumn{2}{|c|}{0.276} & \multicolumn{2}{|c|}{0.373} \\
\hline
\end{tabular}

\section{Discussion}

This study has shown the following: (i) that a 2-step screening procedure for cardiovascular risk evaluation is feasible in a worksite setting and (ii) that a comprehensive program of life-style intervention (special care) at the worksite is superior to usual care in reducing some cardiovascular risk factors, most notably obesity (BMI) and diastolic blood pressure, as well as increasing HDL cholesterol, after 18 months. The changes in the control group were more mixed, including a decrease in glucose and triglyceride levels but improvement in LDL cholesterol. The increase in fasting glucose in this group may merely have been a marker of an aging effect after 1 year of follow-up.

An interesting aspect is that a marker of stress response, morning serum cortisol, was higher at the beginning of the study among the subjects in the intervention group than among those in the control group, but it normalized during the follow-up. This result may eventually have been caused by an initial reaction to alarming information among the subjects of the intervention group with respect to their cardiovascular risk factors and the immediate start of a long-term intensive lifestyle intervention program. Nevertheless, after some time, this initial alarm reaction seemed to have vanished, as no group differences in serum cortisol levels remained in the follow-ups. This interpretation of results is supported by the fact that heart rate, as a marker for sympathetic activation, fell in the intervention group during the study. DHEA did not change in either group, in spite of life-style changes in the intervention group. This finding would imply a possible change in DHEA levels (15). The same was true for plasma insulin.
The increase in the triglyceride levels in both groups is so far unexplained, but it could possibly have been secondary to a change in dietary habits.

One shortcoming of the study was that several participants dropped out or were excluded due to interfering illness or a change in medication, thus violating the study protocol. Nevertheless, a majority remained in the study for the entire 18 months, 89 of the 113 subjects (of 128 invited) who attended the baseline health examination. As the study sample was small, the study can also be regarded as a pilot study that should preferably be followed by larger confirmative studies using a similar design (eg, a 2-step screening method).

Earlier studies have shown that the worksite is a suitable arena for cardiovascular screening and intervention for risk factors (9), even if positive effects are sometimes very modest (11). Clinical improvements have been shown for a reduction in blood pressure, cholesterol, and smoking rates $(9,16-17)$. These studies have mostly been carried out among men, and therefore data from studies involving middle-aged women are often lacking. An earlier study from a large car factory in Sweden (Volvo) has shown that women who report good health also have low levels of risk factors, in contrast to many men, for whom this correlation between health status and risk factors is not as straightforward (18). In the same study no deterioration in quality of life and subjective well-being was recorded after a lifestyle intervention program resembling the one used in our study (19).

Another aspect is the evaluation of cost-effectiveness associated with a worksite screening and prevention program. This aspect was not included in our study, but an indication of the health economic benefits is the 
fact that the mean number of sick days decreased in the intervention group but not in the control group. Future studies should look further into this aspect and include measures of the financial costs and benefits associated with intervention programs. Especially the substantial time spent by staff members should be taken into account.

In conclusion, several cardiovascular risk factors can be improved and morning serum cortisol can be normalized using a life-style intervention program with a randomized design in a worksite population of middle-aged subjects. The use of a 2-step screening program, with an initial questionnaire followed by a health check of subjects with elevated risk, is feasible for worksite settings.

\section{Acknowledgments}

We wish to thank the Helsingborg City Council and Arbetsmarknadsförsäkringar (AMF) for their financial support.

The following persons assisted us with the project: Håkan Lindsten, MD, Ing-Marie Södergren, RN, Nils Dahlin, and Jörgen Fransson, as well as other resource persons.

\section{References}

1. Diderichsen F, Hallqvist J. Trends in occupational mortality among middle-aged men in Sweden 1961-1990. Int J Epidemiol 1997;26:782-7.

2. Prevention of coronary risk in clinical practice. Recommendations of the Second Joint Task Force of European and Other Societies on Coronary Prevention: summary of recommendations. Eur Heart J 1998;19:1434—503.

3. $1999 \mathrm{WHO} / \mathrm{ISH}$ guidelines for the management of hypertension. J Hypertens 1999; 17:151—83.

4. Hjermann I, Holme I, Leren P. Oslo study diet and antismoking trial. Am J Med 1986;80:7-11.

5. Björklund CV, Bengtsson C, Carrazo B, Palm L, Tarschys G, Wassen A. Effects of a community risk factor reducing program on weight, body fat distribution, and lipids in obese women. Int J Obes 1991;15:251—8.
6. Nilsson P, Lindholm L, Scherstén B. Lifestyle changes improves insulin resistance in hyperinsulinemic subjects: a one-year intervention study of hypertensives and normotensives in Dalby. J Hypertens 1992;10:1071-8.

7. Hellénius M-L, de Faire U, Berglund B, Hamsten A, Krakau I. Diet and exercise are equally effective in reducing risk for cardiovascular disease: results of a randomized controlled study in men with slightly to moderately raised cardiovascular risk factors. Atherosclerosis 1993;103:81—91.

8. Persson L-G, Lindström K, Lingfors H, Bengtsson C. Results from an intervention program dealing with cardiovascular risk factors: experience from a study of men aged 33-42 in Habo, Sweden. Scand J Prim Health Care 1996;14:184-92.

9. Kornitzer M, De Backer G, Dramaix M, Kittel F, Thilly C, Graffar M, et al. Belgian heart disease prevention project: incidence and mortality results. Lancet 1983;1:1066-70.

10. Strandberg TE, Salomaa VV, Vanhanen HT, Naukkarinen VA, Sarna SJ, Miettinen TA. Mortality in participants and non-participants of a multifactorial prevention study of cardiovascular diseases: a 28 year follow up of the Helsinki businessmen Study. Br Heart J 1995;74:449—54.

11. Hanlon P, McEwen J, Carey L, Gilmour H, Tannahill C, Tannahill A, et al. Health checks and coronary heart risk: further evidence from a randomized controlled trial. BMJ 1995;311:1609-13.

12. Rose G, Bengtsson C. Evaluation of a laboratory health examination program in a Swedish industry (Volvo). Scand J Clin Lab Invest 1991;51:155-60.

13. Hemingway H, Marmot M. Evidence based cardiology: psychosocial factors in the aetiology and prognosis of coronary heart disease: systematic review of prospective cohort studies. BMJ 1999;318:1460-7.

14. Sapolsky RM, Krey LC, McEwen BS. The neuroendocrinology of stress and aging: the glucocorticoid cascade hypothesis. Endocr Rev 1986;7:2840-301.

15. Ebeling P, Koivisto PA. Physiological importance of dehydroepiandrosterone. Lancet 1994;343:1479—81.

16. Frommer MS, Mandryk JA, Edye BV, Healey S, Berry G, Ferguson DA. A randomized controlled trial of counseling in a workplace setting for coronary heart disease modification: effects on blood pressure. Asia Pac J Public Health 1990;4:25-33.

17. Deacon SP. Screening for cardiovascular risk factors in occupational health practice. J Soc Occup Med 1991;41:126-8.

18. Rose G, Sivik T, Delimar N. Gender, psychological wellbeing and somatic cardiovascular risk factors. Integr Physiol Behav Sci 1994;29:423-30.

19. Rose G, Bengtsson C. Effects of a health examination program on quality of life and subjective well-being. Scand J Soc Med 1996;24:124-31.

Received for publication: 23 September 1999 